\title{
Phospholipid Phosphatase 3
}

National Cancer Institute

\section{Source}

National Cancer Institute. Phospholipid Phosphatase 3. NCI Thesaurus. Code C105943.

Phospholipid phosphatase 3 (311 aa, $\sim 35 \mathrm{kDa}$ ) is encoded by the human PLPP3 gene.

This protein is involved in both cell signaling and diacylglycerol metabolism. 